\title{
МИКРОКЛОНАЛЬНОЕ РАЗМНОЖЕНИЕ КАРТОФЕЛЯ В IN VITRО
}

\author{
Кантарбаева Э.Е., \\ Доктор PhD кафедры «Агрономия и лесоводство» \\ магистрант 2 курса по спещиальнгости Биотехеология Кушершина А.С., \\ студент 3 курса по специильности Биотехнология Тажиева А.А. \\ (Северо-Казахстанский университет имени Манаша Козыбаева)
}

\begin{abstract}
Аннотация. В области проблем, решаемых в растениеводстве с помощью метода культуры тканей, вегетативное микроклональное размножение растений наиболее подробно изучено и широко внедрено в производство. Наибольшие практические результаты достигнуты на основе этой технологии и создана биоиндустрия микроклонального размножения растений. Из статьи можно будет получить представление об изученности данного вопроса.

Abstract. In the field of problems solved in crop production using the tissue culture method, vegetative microclonal reproduction of plants has been studied in the most detail and widely introduced into production. The greatest practical results have been achieved on the basis of this technology and the bioindustry of microclonal reproduction of plants has been created. From the article it will be possible to get an idea of the study of this issue.

Ключевые слова: микроклональное размножение растений, посадочный материал, картофель, in vitro.

Keywords: microclonal reproduction of plants, planting material, potato, in vitro.
\end{abstract}

Актуальность: Впервые микроклональное размножение было проведено французским ученым Ж. Морельом на орхидеях в 50-е годы XX века. В своих работах он использовал технику выращивания верхушечной меристемы растений. Полученные таким образом растения были свободны от вирусной инфекции.

По оздоровлению растений методом меристем и по клональному микроразмножению начались в 60-х годах в Институте физиологии растений им. К.А.Тимирязева АН СССР академии наук СССР [1].

Микроклональное размножение - получение in vitro растений, генетически идентичных исходному экспланту (метод вегетативного размножения растений в культуре in vitro). В основе микроразмножения лежит уникальное свойство соматической растительной клетки тотипотентность - способность клеток полностью реализовать генетический потенциал целого организма [2].

В настоящее время все большую актуальность приобретают различные методы микроклонального размножения сельскохозяйственных культур (прежде всего вегетативно размножаемых) в системе in vitro: размножение пазушными и адвентивными почками, непрямой морфогенез, соматический эмбриогенез.

Использование этих методов дает возможность:

- ускорять селекционный процесс, в результате этого сроки получениятоварной продукции сокращаются до 2-3 лет вместо 10-12;

- получать за короткий срок большое количество оздоровленного, безвирусного материала, генетически идентичного материнскому растению;

- работать в лабораторных условиях и поддерживать активно растущие растения;

- размножать растения практически без контакта с внешней средой,что исключает воздействие неблагоприятных абиотических и биотических факторов;

- получать максимальное число растений с единицы площади;

- в короткий срок получать большое число растений трудно размножаемых;

- при выращивании растений с длительной ювенильной фазой можно ускорять переход от ювенильной к репродуктивной фазе развития;

- длительно (в течение 1-3 лет) сохранять растительный материал в условиях in vitro (без пассирования на свежую среду) [3, 4];

-создавать банки длительного хранения ценных форм растений;

- разрабатывать методы криосохранения оздоровленного in vitro материала $[5,6]$.

Новизна: Выявлены оптимальные питательные среды при микроклональном черенковании растений in vitro сортов Невский, Удача в зимний периоды.

Цель исследований-изучение и совершентсвование питательной среды для увеличения коэфициента размножения на сортах.

Основная задача при этом состовляет в регулировании скорости роста растений из черенков на питательной среде. Поиски велись в двух направлениях: подобраьб питательную среду, котораяобеспечила бы высокий коэффициент размнождения, т.е максимальный выход растений из микрочернков в минимальные сроки. 
Условия, материалы и методика. Исследования провели в лаборатории «Биотехнология сельскохозяйственных растений» СКУ им. М.Козыбаева с сортами Невский и Удача, в период интенсивного размножения - зима.

Схема опыта:

\begin{tabular}{|c|c|c|c|c|}
\hline \multirow{2}{*}{ Компоненты питательной среды } & \multicolumn{5}{c|}{ Питательная среда } \\
\cline { 2 - 5 } & $\begin{array}{c}\text { Мурасиге- } \\
\text { Скуга } \\
\text { контроль }\end{array}$ & Уайта & $\begin{array}{c}\text { Нича, } \\
\text { Нич }\end{array}$ & Гамборга и Эвелега \\
\hline \multicolumn{2}{|c|}{ Макро и -микроэлементы } \\
\hline Сахароза г/л Регуляторы роста & 30000 & 10000 & 20000 & 10000 \\
\hline Гиббереллин & 1,0 & - & 3,0 & - \\
\hline Кинетин & 0,01 & - & - & 0,25 \\
\hline Аденин & - & - & 0,25 & 0,25 \\
\hline ИУК & 2,0 & - & 1,0 & - \\
\hline Аскорбинова кислота & - & - & 3 & 5 \\
\hline
\end{tabular}

Черенкования проводили через каждые 15-20 дней. В процессе размножения in vitro. Поддерживаются оптимальные условия температура и освещенности: постоянная температура $+20-23 \mathrm{C}$, относительная влажность воздуха - 70-80\%, фотопериод - 16 часов, освещенность - от 3 до 8 тыс.лк [7].

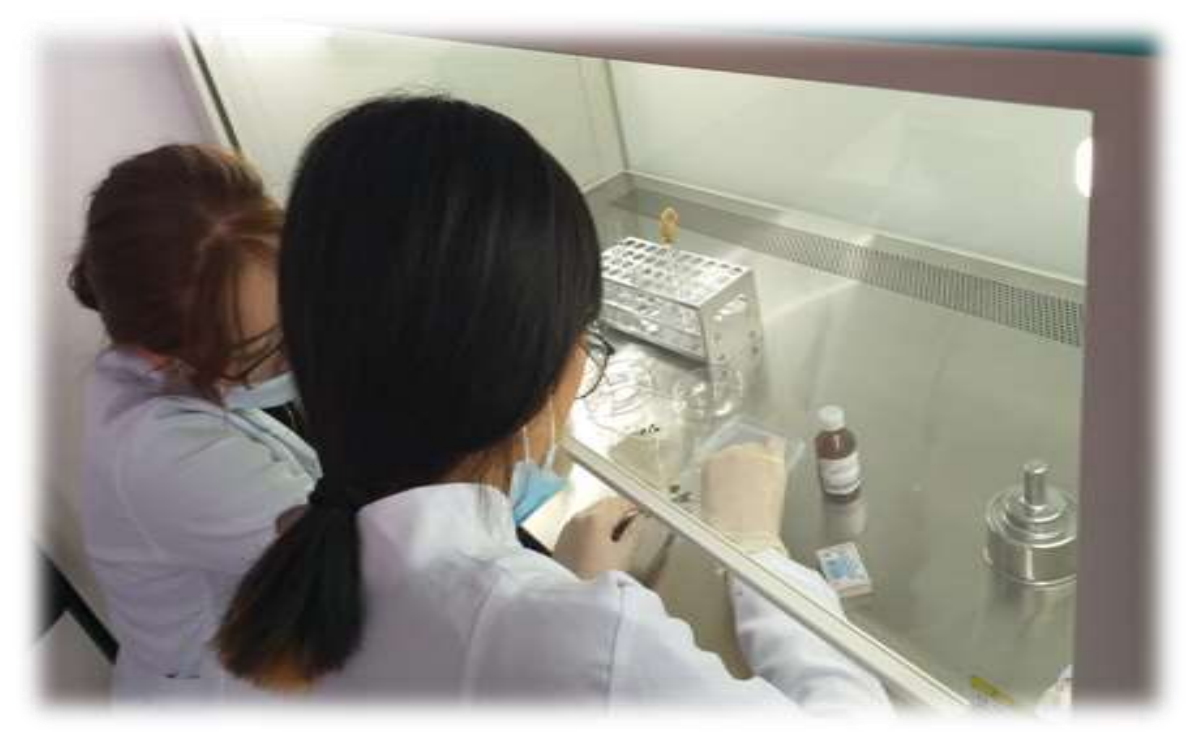

Рисунок 1 - Черенкование картофеля сорта Невский

Результаты и обсуждения. Как показали результаты исслдедований, в зимний период развитие микрорастений сортов Невский, Удача. различно в зависимости от состава питаельной среды и сортовых особенностей. В таблице №1 комплексный анализ основынх показаьелей морфогенеза микрорастений в зависимости от состава питаельной среды. 


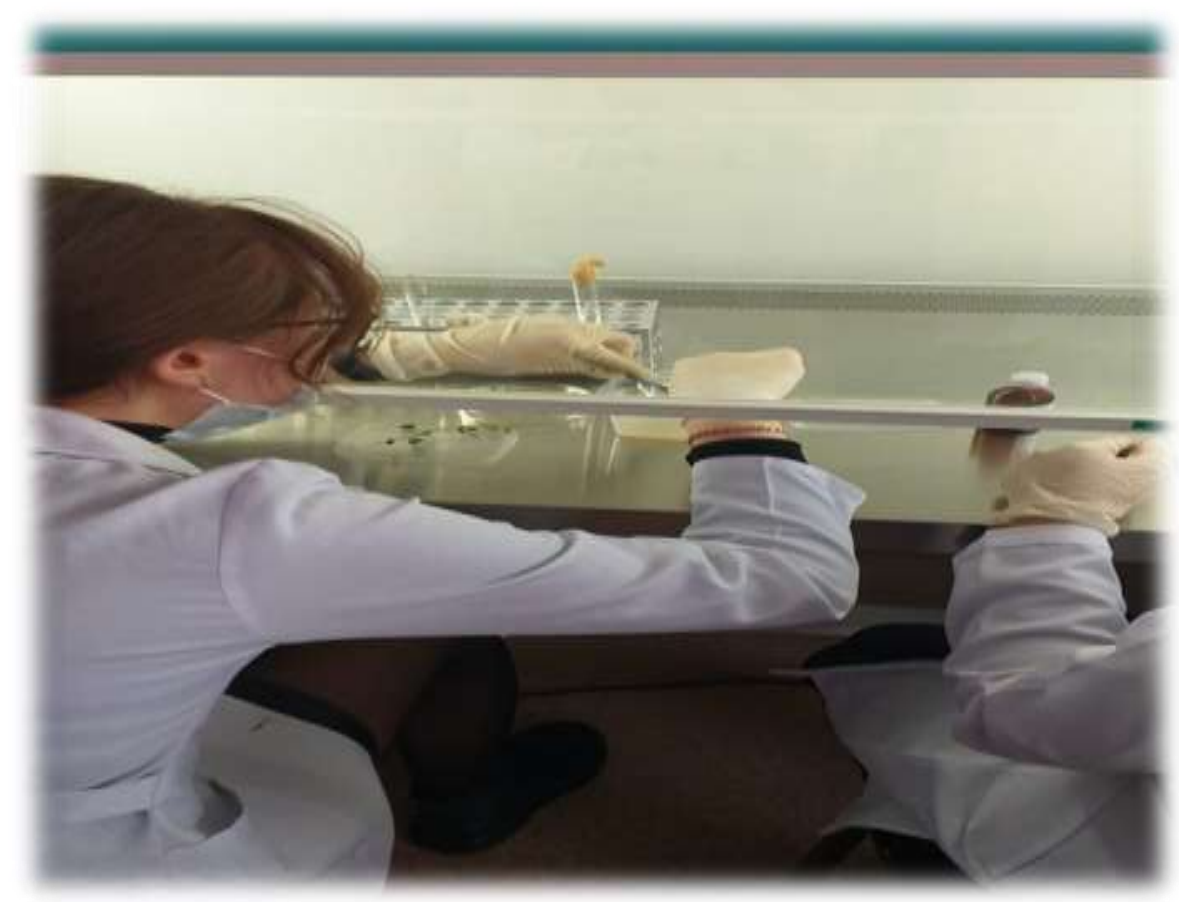

Рисунок 2 - Черенкования картофеля сорта Удача

Наибольшая высота растений у сорта Невский на питательной среде, которой содержат регуляторы роста гиббереллина, и чем выше концентрация вещества, тем выше высота растений: Уайта - 5,3 см, Гамборга и Эвелега - 9,6 см, на среде Нича, Нич с наибольшей концентрацией гибереллина и отсутвием кинетина - 8,5 см, Мурасиге-Скуга (контроль) - (7,5 см).

Одним из важных показателей является количество сформированных междоузлий. Чем выше их выход, тем больше микрорастений можно получать при черенковании в процессе ускоренного размножения оздоровленных растений. Полученные результаты показывали, что у сорта Невский максимальное количество междоузлий сформировались на средах Гамборга и Эвелега, Нича Нич 4,0-4,2 шт и прибавка составила от 0,6-0,8 шт по отношениюк контролю. По количеству корешков на всех средах с пониженным содержанием ИУК отмечено снижение от 3,5 шт (Уайта). Прибавка по длине корешка на среде Гамборга и Эвелега и Нича Нич 24,3-30,2 мм (контроль 29,3 мм).

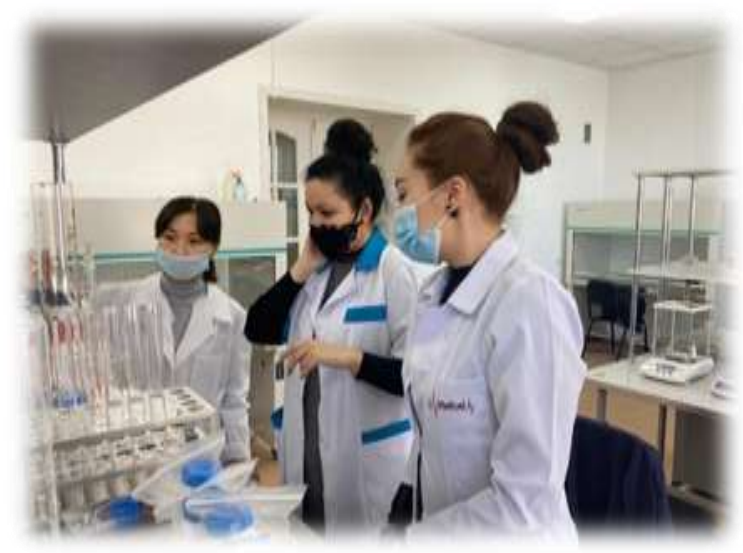

Рисунок 3 - работа в лаборатории «Биотехнология сельскохозяйственных растений» СКУ им. М.Козыбаева 
Таблица 1

Морфогенез мкрорастений при использовании питательной среды различного состава, зимний период.

\begin{tabular}{|c|c|c|c|c|c|c|}
\hline \multirow{3}{*}{ Сорт } & \multirow{2}{*}{ Состав питательной среды } & \multirow{2}{*}{ Высота растений, мм } & \multirow{2}{*}{ Количество междоузлий, шт } & \multicolumn{3}{|c|}{ Корнеобразование } \\
\cline { 5 - 7 } & М-С контроль & 7,5 & 3,5 & 4,8 & 24,0 & 0,18 \\
\hline \multirow{4}{*}{ Невский } & Уайта & 5,3 & 2,6 & 3,6 & 23,0 & 0,11 \\
\cline { 2 - 7 } & $\begin{array}{c}\text { Нича, } \\
\text { Нич }\end{array}$ & 8,5 & 4,5 & 6,8 & 55,3 & 0,30 \\
\cline { 2 - 7 } & Гамборга и Эвелега & 9,6 & 4,8 & 7,5 & 30,2 & 0,30 \\
\hline \multirow{5}{*}{ Удача } & М-С контроль & 6,9 & 3,1 & 5,8 & 20,3 & 0,20 \\
\cline { 2 - 7 } & Уайта & 4,3 & 2,4 & 2,4 & 15,3 & 0,05 \\
\cline { 2 - 7 } & $\begin{array}{c}\text { Нича, } \\
\text { Нич }\end{array}$ & 8,9 & 4,4 & 6,6 & 36,5 & 0,15 \\
\cline { 2 - 7 } & Гамборга и Эвелега & 9,1 & 4,9 & 7,8 & 30,8 & 0,28 \\
\hline
\end{tabular}

На развитие микрорастений сорта Удача благотворно сказалось отстутствие в среде регуляторов роста кинетина, на среде Нича Нич получено увелечение по высоте растений на 1,3-1,5 см. Наибольшее количество междоузлий и длина корешков сформулировалась на средах Гамборга и Эвелега, Нича Нич - количество междоузлий 4,3-4,8 шт, (контроль 3,2) и длина корешков составила 20,3-32,1 мм (контроль 18,6 мм).

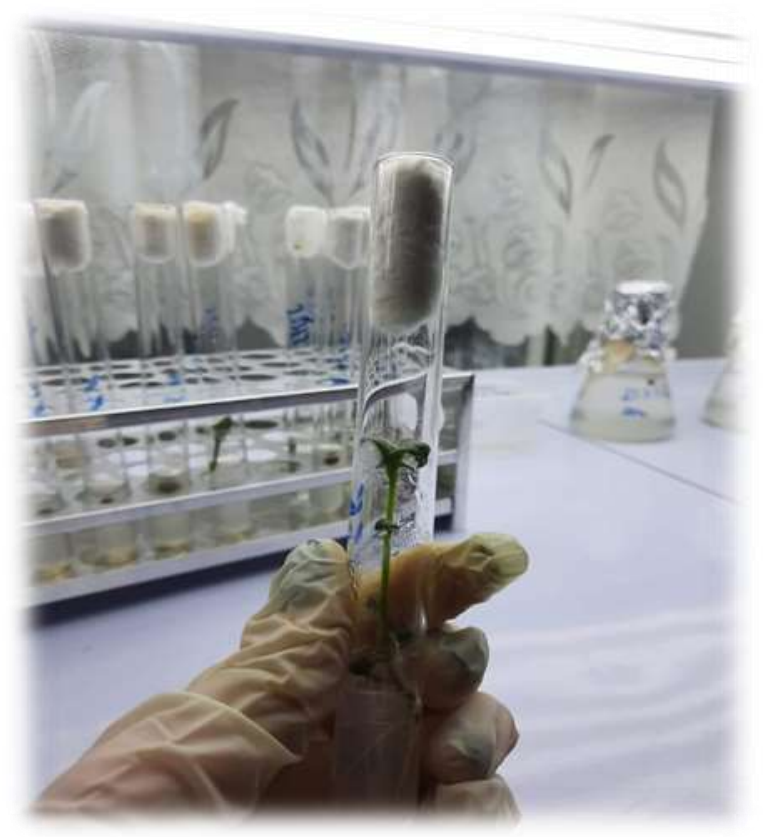

Рисунок 4 - сорт картофеля «Удача» на питательной среде Нича Нич

Отрицательное действие в зимний период оказала на рост и развитие растений изучаемых сортов среда Уайта. Растения не развитые (низкие), листочки свернуты лодочкой, стебли кривые, часто растения ветвистые со слабо развитой корневой системой. При этом вместо корневых волосков были только корневые бугорки, стебли и листочки плохо развитые.

Заключение.

1. Выявлено различное отношение сортов к составу питательной среды - сорта Невский сформировали наибольшее количество междоузлий на средах Гамборга и Эвелега, Нича Нич - 4,0 до 4,2 шт, в зимний период от 4,5 до 4,8. У сорта Удача наибольшее количество междоузлий сформировано на средах бех кинетина Нича Нич 4,2 до 4,6 шт, в зимний период 4,4 до 4,9 шт.

2. Внесниеи в состав питательной среды регуляторов роста гибберилина в концентрации 0,5-2 мг/л способствовало увеличению количества междоузлий сорта Невский на 0,3-0,5 шт/рас по сравнению с конролем. 


\section{Список литературы:}

1.Полевой В. В., Чиркова Т. В., Лутова Л. А. и др. Практикум по росту и устойчивости растений: Учебное пособие. СПб., 2001. С. 208.

2.Сорокина И. К., Старичкова Н. И., Решетникова Т. Б., Гринь Н. А. Основы ьбиотехнологии растений. Культура растительных клеток и тканей: Учебное пособие 2002. С. 45.

3.Чернец А. М., Абраменко Н. М., Стаканова Р. В. Разработка метода длительного хранения in vitro безвирусных клонов плодовых пород и земляники // Тезисы докладов международной конференции: Биология культивируемых клеток биотехнология

Новосибирск, 1988.

4. Романова Н. П., Ульянова Е. К. К вопросу о хранении мериклонов земляники in vitro // Научнотехнический бюллетень Научно-исследовательского института растениеводства имени Н. И. Вавилова. Л., 1990. Вып. 204. C. $75-79$.

5. Орлова С. Ю. Биологические особенности и селекционная ценность сортов вишни в условиях северо-запада России: Автореф. дис. ... канд. биол. наук. СПб., 2002. 6. Niino Takao, Tashiro Kazuo, Suzuki Mitsuteru, Ohuchi Susumu, Magoshi Jun, Akihama Tomoya. Cryopreservation of in vitro grown shoot tips of cherry and sweet cherry by one-step vitrification // Scientia Horticulturae. 1997. Vol. 70. P. 155-163.

7. Безвирусное семеноводство картофеля. Рекомендации. М. ВО «Агропромиздат»-1990- 32 с. 2010 №7. - С. 16-17

8. Анисимов Б.В., Смолеговец Д.В., Шатилова О.Н. Рекомендации по технологии выращивания in vitro микроклубней и их использования в процессе оригинального семеноводства (рекомендации) /Россельхозакадемия; ВНИИКХ. М., 2009. 21 с. 